\title{
Critical theory and social inequality
}

Boike Rehbein*

The relation between science and society has been discussed by all proponents of critical theory. And all of them have linked it to inequality in a similar way. However, most of them interpreted inequality as an economic issue, as an unequal distribution of economic capital. This interpretation presupposes a full-fledged capitalist society and thereby implies a strong Western bias. And it also distorts the relation between capitalism and inequality. According to the argument of this paper, inequality is more fundamental than the economy and capitalism, not the other way around. The misinterpretation of capitalism contributes to the persistence of inequality and capitalism itself. Therefore, we have to critically review our interpretation of inequality. The following argument is based on more than a decade of empirical research on inequality in several countries around the world (Jodhka et al, 2017). It includes almost 2,000 qualitative interviews in twelve nation states on four continents. The interviews were conducted in the local languages, transcribed and interpreted by multicultural teams. A few quantitative surveys complemented the study. This paper will not present the empirical findings of our research on inequality but draws some general conclusions relevant for critical theory. However, some results of that research on Brazil, Germany and Laos will appear in the final section of the paper. The first two sections deal with the relation between subject and object as well as the relevance of inequality in the social sciences. The third section is devoted to 
the relation between inequality and capitalism, while the final part looks at the reproduction of inequality.

Hermeneutic, critique and social sciences

Any social science has to be critical. In principle, even Karl Popper would agree with that. A theory has to critically review its own presuppositions. And it develops a tentative truth, which needs to be subjected to critical reasoning as well as empirical tests. According to these standards, any science is critical, even in the natural sciences. The social sciences need to go beyond this notion of critique, however. This is due to the logical interdependence of subject and object, which does not exist to the same degree in the natural sciences.

The interdependence of subject and object in the social sciences has three aspects. First, the object influences the subject. The natural scientist constructs his or her concepts independently of the object - no natural object says, "I am an atom". In the social sciences, the concepts, the aims, the issues and the organization of science are part of the object itself. Concepts like society, subject and science were created by society, the scientific object itself. This is even true for some of the more technical concepts. Science takes place in a society and cannot operate fully independently of it.

The second aspect of the logical interdependence is the influence of the subject on the object. Of course, this has already been discovered in the natural sciences as well with the problem of measuring very small objects. However, the problem is much more serious in the social sciences. After a theory is published, the object can alter his or her behavior on the basis of this theory. Marxist revolutions are an example of this. Is the revolution proof of the theory or caused by the theory? This question cannot be answered, which illustrates the interdependence.

Finally, the scientific subject and the object often change their own life because of science. Any insight has consequences for the perspective on the world. One learns new theories, discovers new facts, sees reality from a different angle and changes one's self-perception. After each discovery in the social sciences, one is not the same person anymore. It is not possible to predict these changes.

There is no way to neutralize these influences. One would have to find a language, which is not influenced by any existing language, and one would have to detach the enterprise of science completely from society including the scientists themselves. If this project were to succeed, however, one would miss a big part of the object, i.e. society. In the social sciences, we know - at least to a certain degree - which meaning the object gives to itself, what its goals and priorities are, how it views the world, what its behavior means, what kind of emotions are attached to it and a lot 
more. And we know all of this because of the logical interdependence of subject and object. We know very little or nothing of this with regard to the natural world. If we model the social sciences according to the natural sciences, we would lose all of this knowledge.

To discard this knowledge is not equivalent to become more objective or scientific. It rather means to become more arbitrary and formalistic. A scientist who is actually not influenced by society and wishes to explain a social fact will have to understand the meaning of this fact first. The scientist approaches an animistic ritual without knowing what it is and what it means. It could be a game, the election of a president, the healing of a sick person or a bonding exercise. But actually, this assumption presupposes that the scientist is member of a society and already familiar with such concepts and actions. Thereby, he or she would be influenced by society - and could influence the object and change his or her own personality in the process of scientific explanation.

For this reason, a completely objective scientist (an alien or a machine) would have to assume that the observed animistic ritual could be anything. How would the scientist find out what it actually is? If he or she just explains the observed processes, the explanation would read somewhat like this: if person A bangs a drum, persons B and C move their heads forward. Of course, this movement could be just a coincidence but how would the scientist be able to tell? He or she might be able to observe many such rituals, then establish some similarities and statistically determine correlations between certain movements.

Even if we grant that it is possible to correctly identify correlations on this basis (which actually would be very difficult and uncertain), what would we have gained? Who cares if people move their heads upon hearing a drum? What we actually want to know is what the ritual means. In view of this goal, we first have to have the concept of a ritual. And this is social and connected to values and meanings. In the social sciences, we do not know too little, we know too much. And the lack of neutrality and objectivity is actually an asset. We know a lot and we want to know even more. In contrast, we know comparatively little about the natural world.

Things get even more complicated when we look at the object itself. The object is a human being or linked to a human being. This being is of a similar nature as the scientist. He or she can change on the basis of science - or even alter his or her behavior just to prove the scientist wrong. This means that it is not possible to test an explanation in the social sciences in the strong sense of the natural sciences (Von Wright, 1974). Did the Marxist revolution happen because of Marx or did he predict it correctly? Does the absence of a Marxist revolution prove him wrong or are some of the conditions lacking or did people develop the wrong consciousness - or did 
they learn something Marx did not yet know? It is impossible to give a reasonable answer to these questions.

If we assume that we understand the functioning of societies better some time in the future and are able to reply to these questions, the problem will still persist. Let us suppose that a social scientist is actually able to explain society. This would mean that he or she can predict people's actions. Since he or she is member of a society as well, it implies that the scientist can predict his or her own life. Thereby, he or she would lose all personal autonomy. We could interpret this as a change of the person on the basis of science: the self-interpretation as a completely determined being. Or we interpret it as the full knowledge of the truth. We cannot exclude the possibility that our behavior is predetermined or that we are controlled by a higher force. However, this would not really change anything. It would mean that even our scientific insights and the actions based on these insights are pre-determined. But since everything would be pre-determined, we cannot do otherwise anyway. We cannot quit doing science or making revolutions because no matter what we would like to do it would have been predetermined before the fact. And if we actually quit doing science, this would have been predetermined as well. So, we just go on.

From these considerations, we can draw some conclusions about the particularities of the social sciences as opposed to the natural sciences. The social scientist has to understand the meaning of the object before entering into any kind of explanation. At the same time, the scientist always has some kind of preunderstanding of the object, which is the point Hans-Georg Gadamer (1960) made when postulating that the humanities pursue a hermeneutic approach rather than an explanation modeled after the natural sciences.

This preunderstanding of the object seems to be a functional equivalent of the hypothesis in the natural sciences. The test of the hypothesis in the social sciences would be the confrontation of the preunderstanding with the self-interpretation of the object. The interdependence implies that the object can contradict the scientist. The object can contradict the scientist's interpretation. He or she can even contradict the scientific theory itself. However, the relation between preunderstanding and scientific hypothesis is only that of a resemblance since the preunderstanding and its confrontation with the self-interpretation are just preparatory steps. The scientific process itself is an explanation, which challenges both the preunderstanding and the self-interpretation. The scientific preunderstanding of the ritual may be that of a healing process, the self-interpretation that of a ritual but the tradition may have started as a bonding exercise which was then reinterpreted by the community. All interpretations explain an aspect of the observed action, (in this case) none is entirely wrong, and none is true for itself. 


\section{Epistemology, ethics and inequality}

The interdependence of subject and object in the social sciences has epistemological and ethical implications. A neutral, value-free social science, as proposed by Max Weber (1965), is impossible. Even a neutral description of the object is not feasible. It makes a huge difference if we describe an observed set of actions as an animistic ritual, as a healing procedure or as a bonding exercise. These practices pursue very different goals. Even if we do not ask the question whether the practices are successful, we still construct rather different objects depending on the interpretation. We do not look at the same practices and meanings if we try to explain a ritual, a healing procedure or a bonding exercise. And if we discard all value-imbued concepts and just describe what we see, we miss the point entirely, as I have argued in the preceding section. We need to know the meaning of the observed practices before explaining them.

The meaning is socially constructed. It does not matter, in this context, if we rely on the meaning that the practices have for the agents or on scientific constructions, such as the "subconscious" or "class interests". Any meaning has its origin in some social practice, i. e. in the object itself. And any scientific explanation alters the object at some point. The explanation of a set of practices as a ritual, healing or bonding will eventually reach the persons that carry out these practices and change their self-interpretation and possibly the practices themselves. Even if they never get in touch with the scientists and do not read their work, representatives of the state or NGOs will adjust their behavior to the scientific explanations and thereby influence the object.

This is hard to accept. We strive for objectivity and are inclined to say that a statement is true or false. If we predict the result of an election, the prediction is true or false or at least statistically correct (Hempel, 1962). However, it is well-known that election predictions influence the outcome. In order to actually scientifically test a prediction, it needs to be kept secret until the election is over. In such isolated cases, some degree of objectivity is possible. They remain isolated because the results of the election prediction and their methodology will become known to some degree and thereby influence all other election research and the strategies of political parties. An objective reproduction of the prediction is hardly possible since it will influence the object eventually.

Finally, the election prediction will influence the scientist's behavior. He or she will adapt future voting behavior and possibly the interpretation of the meaning and usefulness of elections to the research results. Even if the person is not member or supporter of any political party (which he or she often is, however), the behavior at the polling station of this particular person will be influenced by his or her own research. 
The epistemological consequence of this interdependence is the necessity of critically reviewing the underlying assumptions of society and social science and tracing their impact. This is linked to values since society is not merely the attempt of knowing the truth but also a network of lives. To a small but inextinguishable degree, this is the case for science itself as well. This implies that social science can never be fully dissociated from its own social conditions. Therefore, it cannot be universal in the strong sense, even if the relevant social conditions were shared by all societies. They may change in the future.

A social scientist has to critically reflect on the social conditions of his or her own science. He or she also has to clearly identify the social conditions of the object. Any insight gained in the social sciences is only valid for the reflection on the particular social conditions of the object and the subject. The research has to include its theoretical, methodological and empirical grounds and limitations. It is not valid for all instances but for those specified and to the degree that their social conditions have been critically reviewed. This is more than relativism but less than a universal truth.

I would argue that this practice comes close to what we try to do in the social sciences anyway. A true statement clarifies what can be known from a certain perspective for a defined period and object, including why and how. The statement achieves more truth by including more empirical cases, more areas of research and more methods, especially if it integrates similar research in different contexts and theoretical traditions. This interaction leads to the discovery of limitations, blind spots and flaws and broadens the empirical reality, which the statement refers to. I call this process of establishing a truth "configuration" (Adorno, 1975). I claim that much empirical research actually proceeds by establishing configurations.

The idea of a configurational social science implies a hermeneutical approach to research. There is no basic truth that could serve as the starting point, no (formally clear) result or endpoint and no recipe. All that is possible is to establish configurations, contrast them with new empirical cases and conflicting theories and improve them by removing shortcomings and discovering blind spots from other perspectives. I have elaborated on this process under the title of a "kaleidoscopic dialectic" (Rehbein, 2015).

This dialectic resembles the approach proposed by Hegel (1986). More precisely, it can be characterized as a sociological revision of Hegel. As a result, Hegel's God and his assumption that every theory is part of God's universal truth disappear. A history of social and intellectual standpoints replaces the notion of history as the manifestation of truth (Haraway, 2008). That history contains the interaction of standpoints along with their related conditions and consequences. There is a great variety of perspectives and theories, all of which cannot be integrated into one single 
approach. This does not entail relativism but is rather entirely empirical in nature: we can only think within certain boundaries, which are expanded by constructing configurations. In Hegel's words, the development of the subject, of the perspective and of knowledge takes place within a single context, and we cannot separate the one from the other. Subsequent to the acquisition or discovery of new knowledge, one becomes a new person and sees the world in a different light. Memory and criticism are decisive factors in the process.

This idea of dialectical learning reminds of the "ideal speech situation" (Habermas, 1984) and points to the ethical dimension of the problem. Social science has to deal with different or even competing concepts, theories, perspectives, types of society and values. From the outset, it is not evident whether a certain set of practices is an animistic ritual, a healing procedure or a bonding exercise. It may be all of them at the same time - from different perspectives or for different actors. The different perspectives may represent different theoretical schools, but they may also represent different social groups or types of society. The interpretation implies a value judgement about the arrangement of society.

It is necessary to critically review the social conditions of the subject and the object because they are interdependent with social science itself. It is not sufficient to simply understand all standpoints and then contrast them to form a configuration. First, not all perspectives are equal or have the possibility to enter the configuration. Second, the conditions and the consequences of science may be negatively valued: destructive, exploiting, oppressive, distorting or misleading.

Habermas is satisfied when an agreement is reached. Postcolonialism has challenged this conception by asking why and on what grounds the communicating partners agree (Spivak, 1988). Most people and most approaches to truth do not have the means to make themselves understood. These means can be technological, economic, intellectual, linguistic or academic (Alatas, 2001). As long as it was taken for granted that none of those who did not belong to the European elite of scholars had anything relevant to say because they were supposedly underdeveloped, this lack of means was not an issue. But if we conceive of the hermeneutic dialectic as a process of learning, we have to actively look for that which we do not know (Connell, 2007). One has to understand those who speak another language in their language, those who have a different idea of society within their society and those who have a different idea of or even dismiss truth on their own grounds. Postcolonial critique not only points to the issue of power relations within science. It also exposes parochial Eurocentrism in philosophers like Gadamer or Hegel. As long as science is rooted in European traditions, divergences in epistemology and issues of power can easily be neglected. This is impossible if one tries to include India into the "ideal speech situation". 
However, I disagree with postcolonialism on the interpretation of inequality. Postcolonial scholars, who often reside in Harvard or Oxford, claim that the subaltern cannot speak (Spivak, 1988). Of course, the subalterns have been deprived of important symbolic and material means but they still have their social reality, which they can express. Most postcolonial scholars simply do not bother to talk to them. The approach outlined above comprises the necessity to go and learn empirically, not just at the desk. If one does, it becomes evident that the social world does not consist of two binary blocs, the (bad) dominating and the (good) dominated.

Instead, I would propose a critical theory, which is sociologically applied philosophy and not desk-study (Rehbein, 2015). It needs to be an empirical study of inequality, domination and symbolic violence understood as "quasitranscendental conditions" (Habermas, 1984) of learning. In order to move beyond provincial forms of social science, this study has to be of global reach conducted by multicultural teams, ideally consisting of all members of all societies. They would not generate any universal truth but expand the horizon of society and social science to the degree that one could speak of the best possible knowledge.

Inequality and capitalism

Social inequality limits the scientific process of learning both on the level of social conditions and on the level of practice. Arguably, it is the most significant ethical and epistemological problem of the social sciences. In terms of epistemology, the postcolonial critique has already generated important insights that remind of the arguments advanced by the decolonial critique developed in Latin America (e. g. Mignolo, 2011). As argued in the preceding section, we need to apply the critique of power not only to the organization of science but also to epistemology and the organization of society itself. Against this background, the following paragraphs will develop the claim that the core problem is domination and that domination is structurally rooted in inequality.

Unequal access to science is a major issue connected with inequality. If the social sciences are rooted in the limited perspective of only a fraction of the population, they are neither correct in the sense of a configuration nor are they ethically acceptable. What is worse, if the social sciences do not deal with the problem of inequality with regard to society itself, they contribute to its persistence. This is also true if they misinterpret it. A neutral description of inequality in society is not possible since this description will influence society and thereby either contribute to the persistence or the reduction of inequality. 
This issue lies at the origin of critical theory. The young Marx (Marx, 1953, p. 385), in one of his earliest writings, characterized critical theory as one which contributes to abolishing all conditions, under which the human is a "humiliated, enslaved, lonely and despised" being. This idea was picked up by the Frankfurt School (Adorno, 1975). And to a significant degree, it still inspires recent critical theories, such as those of Habermas and Honneth.

The power differentials within science and with regard to access to science as well as an inhumane society are linked to inequality. We tend to think that inequality is an unequal distribution of resources, especially money. However, any inequality is rooted in social structures that give some social groups more access to socially valued goods, practices and positions than others. This is what I refer to as "domination". It is a structure generating differences in power - or possibilities in a wide sense.

Critical theory so far has been limited by its Eurocentrism. But it is also distorted by its focus on capitalism and the economy. All major critical theorists have claimed that inequality is rooted in the unequal distribution of means of production or economic capital. They argue that the economy is more fundamental than other aspects of society. I wish to dispute this claim. I argue that inequality is more fundamental than the economy. The economy is only the most important dimension of inequality and its reproduction in capitalist societies. However, domination as a structure is more fundamental than capitalism. Inequality in economic capital is the result of structural inequality and not the other way around. And the abolishment of capitalism would not abolish inequality, but the abolishment of inequality would - almost logically - do away with capitalism.

If we pay attention to this issue, we discover that Marx developed two approaches to inequality and distinguished two different systems of class, which we might call economic and social, following Max Weber (1972). In the Communist manifesto (Marx and Engels, 1959), Marx distinguished between the capitalist class, the laboring class, the petty bourgeoisie in between the two and the so-called lumpenproletariat at the bottom. The capital (Marx, 1963), in contrast, mentioned only two classes, capital and labor. Interpretations of Marx have neglected the earlier interpretation of class in favor of The capital, which mainly deals with the economy and ends with the notion of class in an economic sense. However, it is evident that not every manager or actor, who makes a lot of money, has enough economic capital to act as a capitalist or automatically becomes a member of the upper class. But it is true that every family of the upper class that does not play the game of capitalism will eventually lose its membership of the upper social class.

This illustrates the relationship but also the difference between social and economic class. Even the upper social class has to reproduce its position in a capitalist 
society using the economy and economic capital. They may go bankrupt, while others may accumulate enough wealth to become members of the economic capitalist class. In either case, a change of social class may be the result of a change in economic class. But more commonly, a member of the upper social class will have enough economic as well as cultural, symbolic and social capital to be in a better position in the capitalist market than any competitor from the lower classes and therefore remain in the upper class (Bourdieu, 1984).

Membership in the upper social class opens up all options for becoming or remaining a capitalist, while membership in the upper economic class without other types of capital only qualifies for being rich. Therefore, social class is more fundamental than economic class. This can be verified historically. Most people occupy a similar relative social position as their ancestors. Often, the social position can even be traced back to a corresponding social position in the precapitalist hierarchy (Jodhka et al., 2017). That is, the descendant of a peasant usually is a member of the lower class today, while the descendant of a noble family is member of the upper class. The introduction of capitalism was a revolution, but a revolution is not a creation out of nothing. It entails socioeconomic mobility, separates social structure from the division of labor and creates a whole new range of professions for all social groups. But it does not abolish older inequalities, it only transforms them and makes them invisible.

Edward P. Thompson (1963) demonstrated the continuity and transformation of a class with the advent of capitalism in England. He defined classes not merely on the basis of capital but also interpreted them as cultures with a common practice. His central argument was that practices are not created spontaneously but are passed on through training from one generation to the next. On the one hand, these practices are subject to constant change because they relate to and influence each other, on the other hand, they create and continue long traditions. Therefore, we can characterize social classes as "tradition lines" (Vester et al., 2001).

A social class or tradition line passes on core elements of habitus and capital from one generation to the next and distinguishes itself actively and passively from other classes. Hereby, it erects limits to social mobility and opportunities. On this basis, it is possible to identify social classes empirically. The limits of social mobility and of access to activities are the limits of a social class. An increase in one type of capital is not equivalent to mobility. Gopal Guru (2012, p. 47) has demonstrated that a Dalit (formerly classified as "untouchable") in India may be able to accumulate all kinds of capital on the free market but still remains excluded. A Dalit millionaire remains a Dalit. Guru adds that a Dalit becoming a millionaire has one main effect, namely the legitimation of capitalism. Most proponents of critical theory were un- 
able to see this because of their focus on economic capital and labor. The successful struggle for economic capital renders the mechanisms of social inequality invisible.

The notion of class proposed in this paper is related to Weber's (1972) concept of social class. I define social class as a tradition line with a common culture which reproduces itself from one generation to the next by passing on relevant capital and symbolically delimiting itself from the other classes (Jodhka et al., 2017). This concept can be operationalized by establishing the limits of social mobility. Where the itineraries of social mobility typically end is the limit of the class. Economic capital is important in a capitalist society but so are all other types of capital identified by Bourdieu (1984).

Reproduction of inequality

Michel Foucault (1977) has argued that the classes in a democratic society are supposed to carry out different functions in the division of labor and have different positions in the institutions. It is interesting to note that Foucault referred to the prime specimen of a democratic society, France after 1789. Foucault demonstrated the persistence of classes and their transformation within a democratic state with regard to the legal system. While civil law mainly concerned (bourgeois and noble) citizens and their property, the system of accusation and punishment mainly concerned the lower classes. Different courts were established to deal with different issues, which concerned different classes.

Our empirical research shows that this division of classes in the legal system is still largely valid for present-day Germany and Brazil (Jodhka et al., 2017). This system is probably not intentionally designed to oppress the lower classes. No malevolent intention and no conscious action is necessary to reproduce the hierarchy of social classes. The differences are incorporated, contained in the meaning of the socially accepted symbols and transmitted from one generation to the next. Formally, all individuals are equal, but their habitus and its evaluation differ according to social class.

In a capitalist democracy, inequality is legitimized by merit and the increase of productivity (Foucault, 1977). The division of labor is no longer based on the order of classes but on the maximum output. To this end, any labor has to be carried out by the person most suitable for it, by the best. This is exactly what happens. In capitalist societies, the "best" carry out the most important functions in the division of activities. The best are those with the appropriate habitus and capital. These are distributed differentially between the social classes. Members of the highest classes occupy the highest functions in the division of activities and define the characteristics required to carry out such a function. They recruit individuals on the basis of these criteria. Unsurprisingly, other members of their class, who embody the same 
characteristics because they grew up in the same environment, are those individuals who meet the criteria best. They are the best.

The reproduction of inequality in capitalist democracies is at the same time riskier and more efficient than a feudal order or a monarchy. As all individuals are formally equal and all institutions are open to everyone, the highest classes have to enter competition. Upward mobility for the lower classes is possible. At the same time, the invisibility of the reproduction of class makes this kind of reproduction more efficient than any open inequality. Class position is also more secure because state systems with visible inequality like the European feudal order are characterized by constant struggles, assaults and even annihilation of ruling families. In a formally democratic society, in contrast, a high social position is based on some kind of achievement, a seemingly objective recruitment of the best. It is legitimized by merit.

The reproduction of inequality becomes even more opaque because of the obvious individualization. There are no visible classes anymore, just competing individuals carrying out a great variety of activities, which they combine to rather unique life courses. Socioeconomic parameters and social position no longer allow for predictions of an individual's lifestyle. Predictions of this kind are for the most part empirically incorrect. What is worse, they contribute to the invisibility of the mechanisms reproducing inequality. It is precisely the apparent individualization that makes these mechanisms functional. It goes hand in hand with a recruitment for important positions, which is apparently based on merit.

The criteria for recruitment are constantly transformed because the capitalist division of activities is constantly revolutionized. However, the criteria applied by those occupying the highest positions are precisely those which they teach their children and which their children incorporate better than other persons (Jodhka and Newman 2007). Those persons occupying the highest positions know best what it takes. This is not taught in any kindergarten or school, simply because very few people know what it takes to run the show.

Members of the highest class occupy the highest positions and have access to the most valued positions, while members of the other classes formally have access to them but are practically excluded because they do not meet the criteria. Which activities are valued and reserved for members of the higher classes is a product of history. It is somewhat irrational and arbitrary but intelligible and consequential. Only the upper class has access to all markets, both for capital and labor. The other classes may have money but actually no economic capital. The manager of a mediumsized company or a university professor may own a house and a car and may even have significant savings in the bank. But nothing of this is used as capital in the strict sense. It is used for consumption and for securing future consumption. 
The social classes in capitalist societies have different relations to capital and labor. There is only one, very small capitalist class, just as Marx has postulated. But there seem to be several laboring classes in all societies. In an empirical study of Germany, we identified four classes, which we called the marginalized, the fighters, the established and the aloof (Rehbein et al., 2015). The marginalized remain excluded from many sections of society, especially a stable and well-paid profession. The social class of fighters forms the laboring population. It consists of two tradition lines, one rooted in the old working class and one in the petty bourgeoisie. In our study, we call them the aspiring and the defensive fighters, since the former traditionally acquire skills and education, while the latter struggle against declassation. The established carry out the leading functions and dispose of a large amount of all types of capital. The aloof are aloof in the sense that they are separated from the rest of society and morally as well as financially exempt from labor. They form the social class, which I would classify as dominant.

Laos has a very different social structure even though social classes are emerging (Jodhka et al., 2017). Here, colonial, socialist and even precolonial social structures persist underneath the capitalist class structure. Within the first, there is a hierarchy of ethnic minorities, peasants in a difficult environment, well-off peasants, urban population and nobility. Within the socialist structure, we can distinguish between village cadres, administration, leading cadres and party leadership; within this structure, there is much more social mobility than in the other two structures since it is possible to move up the ladder of party positions. The capitalist hierarchy comprises the marginalized class, the working class, commercial farmers and traders, the new urban middle class and the capitalists. The older structural layers slowly transform into a capitalist class hierarchy, but the social groups tend to remain on the same hierarchical level. Subsistence peasants, who do not remain peasants, either become commercial farmers or agricultural laborers or they migrate into the towns. The small urban group becomes the new urban middle class. The old elites begin to engage in business and become capitalists. A structure of social classes emerges that is related to the capitalist division of capital and labor.

Brazil, like Germany, has a long history of capitalism and a pronounced class structure. However, it was constructed by colonial rule. Contrary to Laos, not the entire population was declared equal with independence, but slaves, women and ethnic minorities only gained full citizenship over time. These inequalities persist up to this day and inform the Brazilian social structure. We found four classes in Brazil but not exactly the same as in Germany (Jodhka et al., 2017). While dominant and marginalized classes of Germany and Brazil can be compared to some degree, the lower middle class in Brazil does not exist in Germany, while the Brazilian upper 
middle class comprises both of the classes that form the fighters and established in Germany. It is composed of two tradition lines, which are rooted in the colonial administration and in the skilled working class.

While the Brazilian marginalized class comprises up to forty percent of the population, the German marginalized class has a population share of twenty percent. The Brazilian middle class comprises only around 25 percent of the population, while the two German middle classes reach a total of almost eighty percent. We can trace the two Brazilian lower classes to the descendants of the slaves, the middle class to the administrators and immigrants and the dominant class to the colonial rulers and landowners.

Since the Brazilian class structure emerged historically out of the hierarchy of a slave-holding society, its internal configuration and composition differs greatly from that of Germany and Laos. However, all three societies are developing similar dividing lines between the classes. At the same time, the historical differences will not disappear entirely in the near future since they are part of the historical heritage and are reproduced both by habitus and by the (international) division of labor.

In all societies, social scientists overwhelmingly belong to the established class - or the social class below the dominant class. Postcolonialism and decoloniality criticize the structure of international domination, which is rooted in colonialism. But they do not reflect upon the class structure of their own societies and tend to speak on behalf of the lower classes instead of speaking with and listening to them. Those critical theorists who emphasize inequality, such as Marx and Adorno, tend to focus on economic inequality. Thereby, they misunderstand the fundamental importance of domination or social inequality.

Social inequality is reproduced from one generation to the next and becomes invisible in capitalist societies. Everything seems to be about money. While liberals claim that anyone can make it, Marxists postulate that the capitalist class has monopolized economic capital. I have argued that the surface of struggles for money makes the reproduction of inequality at once more invisible and more efficient. Those on the top seem to have earned their position and their money. The focus on economic capital reinforces this myth.

Other forms of inequality function in a similar way as social inequality. In capitalism, they do not disappear, but they are shaped by class more than they shape class. Each class has its own configuration of gender inequality but not each gender has its own class hierarchy. The same is true for other dimensions of inequality. However, for a full understanding of inequality, even in capitalist societies, the intersection of all dimensions would have to be studied in more detail and with some precision. 


\section{Conclusion}

Arguably, inequality is the core issue for any critical theory, for epistemological and ethical reasons. The ethical reasons refer to both science itself and society at large. The main problem with inequality, of course, is not its distorting impact on science but its impact on the real lives of real people. Leading life as member of the dominant class is not the same as being a Dalit in India or living in a Brazilian favela. These differences supposedly are due to differential merit. In a capitalist society, we are all equal and seem to have equal opportunities. Some make it, and some do not. Whoever lives at the bottom of society is to bear at least part of the blame.

The focus on the economy contributes to this view of inequality. Those who acquire a lot of wealth have made it. We engage in a struggle for money, which actually changes nothing about inequality. It rather cements inequality in the form of social classes, which emerge in all capitalist society and become invisible. A social science preaching the ideology of merit and economism contributes to invisibilizing inequality. A critical theory has to take issue with that.

If social science does not study its own conditions and especially inequality, a class perspective is proposed as the fountain of truth. Large sections of society are excluded, not only as subjects of science but also as contributors of meaning and of theoretical perspective. One cannot simply speak on their behalf, but one has to speak with and listen to them. In the long run, critical theory has to become an endeavor that comprises everyone.

\section{References}

Adorno, Theodor W. (1975), Negative Dialektik. Frankfurt am Main, Suhrkamp.

Alatas, Syed Farid. (2001), “Alternative discourses in Southeast Asia”. Sari, 19:49-67.

Bourdieu, Pierre. (1984), Distinction. Cambridge, Harvard University Press.

CoNnell, Raewyn. (2007), Southern theory: the global dynamics of knowledge in social science. Cambridge, Polity.

Foucault, Michel. (1977), Discipline and punish. New York, Pantheon.

Gadamer, Hans-Georg. (1960), Wabrheit und Methode. Tübingen, J. C. B. Mohr.

Guru, Gopal. (2012), "Rise of the 'Dalit millionaire': a low intensity spectacle”. Economic and Political Weekly, 47 (50): 41-49.

Habermas, Jürgen. (1984), Theorie des kommunikativen Handelns. Frankfurt am Main, Suhrkamp, 2 vols.

Haraway, Donna. (2008), When species meet. Minneapolis, University of Minnesota Press. 
Hegel, Georg Wilhelm Friedrich. (1986), Phänomenologie des Geistes. Frankfurt am Main, Suhrkamp.

Hempel, Carl Gustav. (1962), "Explanation in science and history”. In: Colodny, Robert G. (ed.). Frontiers of science and philosophy. Pittsburgh, University of Pennsylvania Press, pp. 9-19.

JoDHKA, Surinder S. et al. (2017), Inequality in capitalist societies. London/New York, Routledge.

Jodhka, Surinder S. \& Newman, Katherine. (2007), "In the name of globalisation: meritocracy, productivity and the hidden language of caste". Economic and Political Weekly, 42 (41): 4125-4132.

MARX, Karl. (1953)“'Zur Kritik der Hegelschen Rechtsphilosophie. Einleitung”. In: MarX, Karl \& Engels, Friedrich. Marx-Engels-Werke, Berlin, Dietz, vol. 1, pp. 378-391.

Marx, Karl. (1963)“'Das Kapital. Band II”. In: MARX, Karl \& Engels, Friedrich. Marx-Engels-Werke. Berlin, Dietz, vol. 25.

Marx, Karls \& Engels, Friedrich. (1959), “Manifest der Kommunistischen Partei”. In: MarX, Karl \& Engels, Friedrich. Marx-Engels-Werke. Berlin, Dietz, vol. 4, pp. 459-493.

Mignolo, Walter D. (2011), The darker side of Western modernity. Durham, Duke University Press.

ReHbeIn, Boike. (2015), Critical theory after the rise of the global south. London/New York, Routledge.

ReHbeIn, Boike et al. (2015), Reproduktion sozialer Ungleichheit in Deutschland. Konstanz, UvK. SpIvak, Gayatri Chakravorty. (1988), “Can the subaltern speak?”. In: NeLson, Cary \& GrossBERG, Lawrence (eds.). Marxism and the interpretation of culture. Basingstoke, Palgrave Macmillan, pp. 271-313.

Thompson, Edward P. (1963), The making of the English working class. Harmondsworth, Penguin.

Vester, Michael et al. (2001), Soziale Milieus im gesellschaftlichen Strukturwandel. Frankfurt am Main, Suhrkamp.

Von Wright, Georg Henrik. (1971), Explanation and understanding. Ithaca, Cornell University Press.

Weber, Max. (1965), Wissenschaft als Beruf. 3. ed. Berlin, Duncker \& Humblot.

Weber, Max. (1972), Wirtschaft und Gesellschaft. 5. ed. Tübingen, Mohr. 


\section{Abstract}

\section{Critical theory and social inequality}

This paper argues that social inequality is possibly the core topic of any critical theory in the social sciences - for epistemological as well as ethical reasons. As the social scientist is part of the scientific object, namely society, the project of science is interdependent with its object. For this reason, the structure of society itself influences the shape of social science. At the same time, the processes and results of the scientific project have an impact on society. Science changes its own object. Epistemological issues are therefore tied to the ethical questions about the social organization of the scientific project, access to science, the structure of society and inequality. If access to science is unequal and if science contributes to inequality, this has to be legitimized scientifically.

Keywords: Critical theory; Social inequality; Science; Ethics and epistemology; Capitalism.

\section{Resumo}

Teoria crítica e desigualdade social

Este artigo argumenta que, por motivos epistemológicos bem como éticos, a desigualdade social é, possivelmente, um tema central de qualquer teoria crítica nas ciências sociais. Visto que cientistas sociais são parte do objeto científico, isto é, a sociedade, o projeto da ciência é interdependente com o seu objeto. Por essa razão, a estrutura da sociedade em si influencia a forma da ciência social. Ao mesmo tempo, os processos e resultados do projeto científico exercem um impacto sobre a sociedade. A ciência transforma o seu próprio objeto. Essas questões epistemológicas encontram-se, portanto, ligadas a questões éticas acerca da organização social do projeto científico, do acesso à ciência, da estrutura da sociedade e da desigualdade. Se o acesso à ciência é desigual e se a ciência contribui para a desigualdade, então isso precisa ser legitimado cientificamente. Palavras-chave: Teoria crítica; Desigualdade social; Ciência; Ética e epistemologia; Capitalismo.

Texto recebido em 1/5/2018 e aprovado em 13/5/2018.

DOI: 10.11606/0103-2070.ts.2018.145113.

BOIKE REHBEIN is professor for "Society and transformation in Asia and Africa" at Humboldt Universität zu Berlim. E-mail: brehbein@gmx.de. 